\title{
Acceptance sent through email; is the postal rule applicable?
}

Submitted: 20/06/2018

Revised: $05 / 07 / 2018$

Accepted: 15/01/2019

\author{
Delphine Defossez*
}

\begin{abstract}
Purpose - This paper focuses on the application of the postal rule to email, due to the controversy surrounding the application of the "instantaneous" test to emails.

Methodology/approach/design - This article analyses standards and literature on the formation of contract under English law.

Findings - Although the postal rule is an invention of its time, this rule could still play a role regarding emails. Indeed, due to the difficulties in applying the "instantaneous" test to emails, emails would still be subject to the postal rule. Of course, the postal rule in its current form is no more fitting the reality. However, the benefits that such rule provides should not be lost, instead a new rule could be drafted based on the postal rule.

Practical implications - This article discusses the possible improvements to the already existing framework.

Originality/value - This paper analyses the use of the postal rule to electronic contracts in the UK, a topic that is not much researched but could have great importance when doing electronic business.
\end{abstract}

Keywords: Postal rule, emails, contract law, acceptance, English law.

\section{Introduction}

A central requisite to the formation of a contract is necessity for an offer and acceptance. The general rule stipulates that acceptance must be communicated and received by the offeror. However, the postal rule is an exception to this general rule, as held in (Brinkibon Ltd v Stahag Stahl und Stahlwarenhandelsgesellschaft $\mathrm{mbH}, 1983)$. A contract is deemed to be formed when the letter of acceptance is posted according to (Adams v Lindsell, 1818).

"Delphine obtained two master's degrees in law, one in Comparative International and European Law from the European University Institute (EUI), Florence, Italy, the other in International Commercial and Maritime Law from Swansea University, United Kingdom. Her Bachelor studies were in European Law at the University of Maastricht, The Netherlands, in which she also was selected for a researched based programme, Marble program, under the supervision of the Dean of the law faculty. E-mail: d.defossez91@gmail.com. 
This means that an offer can no longer be revoked once the acceptance has been posted (Re Imperial Land Co of Marseilles (Harris' case), 1872), and it is generally irrelevant that it never arrives, or arrives late (Household Fire and Accident Insurance Co v Grant, 1874).

The postal rule is an invention of its time, when the main and quickest form of business communication was through the post. However, it is a matter of controversy, whether the postal rule should be applied to e-mail and similarly modern methods of communication. Surely so, when the postal rule that once was very useful nowadays is rarely invoked. The controversy stems from the difficulties to apply the "instantaneous" test to emails. The "instantaneous" test derives from the telex cases that were regarded as instantaneous and therefore were not subject to the postal rule. ${ }^{1}$ There is, however, no agreement as to any such classification of e-mail (Chwee Kin Keong and Others v Digilandmall.com Pte Ltd, 2004; Hill, 2001). The European legislator also avoids classifying email in either 'instantaneous' or 'non-instantaneous' as the Electronic Commerce Directive does not extend to email (Murray, 2005).

The question of the extension of the postal rule to e-mail is of crucial importance and need more consideration as it determines whether acceptance was given and is valid or not. Economic efficiency can be put in jeopardise if the postal rule applies to acceptance send through e-mails. Especially because a customer buying items online will receive a confirmation of order, but the acceptance is executed by the dispatch of the goods themselves. A rule applicable to acceptance through emails is of crucial importance as otherwise, the applicable rule will be obsolete for the technology it regulates.

The revocation is also a problem. Indeed, if the postal rule applies to email, it means that similar revocation issues will exist, as normally the offeror can no longer revoke his offer once the acceptance has been posted. However, if the revocation arrives just when the acceptance was sent through e-mail, then is it a valid revocation? To complicate the matter, under Article 16(2) of the United Nations Convention on International Sale of Goods (CISG), an offer cannot be revoked once the offeree has dispatched an acceptance, although the acceptance will not be effective until received by the offeror.

The application of the postal rule to such newer methods of communication and even to the post itself might no longer be justified. With the progress of electronic methods, the dispatch and receipt of a message tend to coincide. As a result, any law that dealt with the delay between the two, such as the postal rule, seems to obsolete. However, abandoning such rule altogether might neither be the

${ }^{1}$ Entores Ltd v Miles Far East Corporation [1955] 2 QB 327; Brinkibon v Stahag Stahl und Stahlwarenhandels GmbH [1983] 2 AC 34; David Baxter Edward Thomas and Peter Sandford Gander v BPE Solicitors (a firm) [2010] EWHC 306 (Ch) at 86.

DEFOSSEZ, D. Acceptance sent through email; is the postal rule applicable? Law, State and Telecommunications Review, Brasilia, v. 11, no. 1, p. 23-46, May 2019. 
best option. Therefore, the flexibility of the concept will be measured by looking at internet contracts and how they are seen by the courts in England.

This article demonstrates that the postal rule should still play a role with regard to the acceptance of a contract through e-mail. Of course, the postal rule in its current form is no more fitting the reality. However, the benefits that such rule provides should not be lost, instead a new rule could be drafted based on the postal rule. The postal rule is of great importance, especially with regard to revocation and the allocation of risk. At the same time, the application of the postal rule to email create problems, as the categorisation of e-mails as instantaneous means of communication is unsure. The underlying bases of the postal rule need to be looked at in order to answer the main question of this article which is whether the postal rule could apply to e-mails. First the formation of a contract will be briefly discussed to then look at the history behind the postal rule and the telex. Putting the rule in an historical perspective will help understanding the underlying bases of the rule and highlight the benefits of the rule. The next section is dedicated to e-mail and internet contracts. In this section, the discussion about emails qualifying as instantaneous means of communication or not will be analysed, with the author arguing in favour of his position. The problem of revocation of a contract concluded through email will be the focus of the next section. In this subsection the need of the postal rule will become apparent. Finally, the problem of lost emails or delayed emails will be briefly discussed. Although the focus is on the post and e-mail, other methods of communication might be used to demonstrate a point that the author is making.

\section{The Creation of Contract under English law}

English law does not provide a general definition of a contract. A contract is an agreement enforceable by law and also legally binding between the parties. A contract is often defined as a meeting of mind which requires agreement, consideration and an intention to be legally bound (Anon., 2006).

English courts have developed the law on contract formation on the model of offer and acceptance. The first case referring to offer and acceptance dates back to 1818, the Adams $v$ Lindsell (Simpson, 1987). By his offer the offeror expresses his intention to bring legal consequences and by his acceptance the offeree expresses his intention as well. The Court defined, in (Storer v Manchester City Council, 1974), an offer as the parties' declaration to enter into a contract on the terms stated in the offer. Therefore, the need of communication is vital as stated in (Taylor v Laird, 1856).

In order for a contract to be concluded the offeree's acceptance must be communicated and brought under notice of the offeror (Anon., 2006). It stems 
from Adams $v$ Lindsell that acceptance is communicated when a letter of acceptance is posted. English law is based on the principle that every offer is revocable unless it has been accepted. Therefore, an offeror is not bound by is offer unless it has been accepted. The notice of revocation must reach the offeree but does not have to come from the promisor, it can also come from a reliable source (but this creates problems), (Anon., 2006) as in the case (Byrne \& Co v Leon Van Tien Hoven \& Co, 1880). Court could find a contract invalid if any of the essential elements of a contract is missing. The postal rule was adopted as an exception to the general rule. In order to decide whether the postal rule could be applied to emails, it is important to keep the general rule on contract formation and especially that for the acceptance to be valid, the offeror must have received a notice.

\section{The History Behind the Postal Rule and the Telex Cases}

The postal rule is a historical ruling, which came about in a time where the main and quickest form of business communication was by post. Through the evolution of technology, other speedier forms of communication have been invented such as the telex, phone, fax, instant messaging and email. The conclusion of distance contracts has been controversial, raising some questions with regard to the moment a contract is formed. A debate has emerged as to whether the postal rule should govern the conclusion of contract through emails.

\section{The Postal Rule: Acceptance}

The central requisite to the forming of a contract is based on the acceptance of an offer by the offeree. The general rule states that acceptance must be communicated and received by the offeror for a contract to be concluded. The exception to this rule is the postal rule.

The landmark judgment on this issue is the case of Adams $v$ Lindsell. In this case, on the $2^{\text {nd }}$ of September, the defendants offered to sell some wool to the plaintiffs requesting an answer 'in course of post'. The defendants' letter was wrongly addressed and thus the plaintiffs' received it on the $5^{\text {th }}$ of September which delayed their response. In the meantime, the defendants had already sold the wool to someone else when they obtained the letter of acceptance with a twoday delay. The plaintiffs, who had sent the letter of acceptance on the same day, urged that the contract was valid and that the defendants breached the contract. The court agreed with the plaintiff and held that the contract was binding as soon as the letter had been posted. It stems from Adams $v$ Lindsell that acceptance is communicated when a letter of acceptance is posted.

The traditional idea conveyed in this case is that a contract is a meeting of the minds or consensus ad idem. In this perspective, the meeting of the mind 
occurs when the letter of acceptance is dispatched, as at that time both parties intended for the contract to be legally binding. Other countries have taken a similar approach as embodied in Section 4 of the Contracts Act 1950 of Malaysia and in (Ignatius v Bell, 1913). According to section 4(2)(b) of the Contracts Act 1950 , acceptance by post takes effect when the offeree posts the letter and not when the letter reaches the offeror. A letter is considered to be posted when it is inserted in an official letter box or given directly to an authorised employee in the post office.

The rule only applies when it is reasonable to use the post, (Henthorn $v$ Fraser, 1892). So, if the offer was send through the post, the acceptance can be send using the same mean. In Henthorn v Fraser, for instance, the Court ruled that it was reasonable to post acceptance in response to an oral offer as the parties lived away from each other. "Where the circumstances are such that it must have been within the contemplation of the parties that, according to the ordinary usages of mankind, the post might be used as a means of communicating the acceptance of an offer, the acceptance is complete as soon as it is posted." ${ }^{2}$ However, the rule in Adams v Lindsell will normally not apply where, in response to an offer made by telex, telephone or email, the acceptance is sent by post. Another exception to the postal rule is if the acceptor knew that the postal service was disrupted at the time but still decided to dispatch his acceptance.

Once the acceptance is posted, the offer can no longer be revoked, as held in (Imperial Land Co of Marseilles (Harris' case), 1872). It is generally irrelevant that it never arrives, or arrives late, according to the ruling in (Household Fire and Accident Insurance Co v Grant, 1874). However, if the late or non-arrival of the acceptance is due to the fault of the offeree, who has for instance misaddressed the letter, then the rule will not apply as no one can gain from its own fault ( $L J$ Korbetis $v$ Transgrain Shipping BV, 2005, p. 15).

Where post is the requested form of communication or when it is an appropriate mean, the communication of the acceptance is complete as soon as the letter is posted. In other words, unless the offeror has clearly stated in the terms of the offer that acceptance must be communicated by other means the offer must be accepted through the terms of the postal rule (Bressan v Squires, 1974). Even if the letter was delayed or lost and therefore, does not reach the offeror, the offeror is bound when the offeree posts the letter of acceptance (O'Sullivan \& Hilliard, 2006).

In the case, (Holwell securities Ltd $v$ Hughes, 1974) the postal rule was overridden by normal contract law. In this case, the defendant, Dr Hughes, had granted a call option with respect to his property at 571 High Road, Wembley to the claimants, Holwell Securities Ltd, given the claimants the irrevocable right to

\footnotetext{
${ }^{2}$ Paragraph 33.
}

DEFOSSEZ, D. Acceptance sent through email; is the postal rule applicable? Law, State and Telecommunications Review, Brasilia, v. 11, no. 1, p. 23-46, May 2019. 
purchase the property during the option period for the specified sum. It contained a clause stipulating that a written notice should be given within six months to exercise the option. The claimants sent a letter purporting to exercise the option. However, it was lost in the mail and was never received by the defendant. The defendant then refused to complete upon the purchase and the claimants sought specific performance. The court decided that the original offer clearly stipulated the method by which acceptance was to be communicated and therefore, such stipulation superseded the normal operation of postal rule. The postal rule therefore does not apply in every case. Indeed, Russell LJ, applying the case of (Hare v Nicholl, 1966), asserted that options represent a special case and that the postal rule does not apply when the offer contains express terms which exclude the rule. This includes excluding it by implication where the offer specifies that acceptance must reach the offeror. Additionally, although obiter dictum, the Court of Appeal added that the rule ought not to apply in cases where its application would produce manifest inconvenience and absurdity. Therefore, if when looking at all the circumstances, it appears that the parties could not have intended a binding agreement until notice of acceptance was communicated to the offeror, then the rule would not apply. Unfortunately, such statement does not have a binding effect.

Where the method of communication is stipulated by the offeror, it must use clear wording for the method to be used mandatorily. In (Yates Building Co. Ltd v RJ Pulleyn \& Son (York) Ltd, 1975), the acceptance was to be sent by "registered or recorded delivery post". The plaintiff sent his acceptance through normal post service, which was refused by the defendant as it was not by one of the methods outlined in the offer. Both the court at first instance and the Court of Appeal found that there was a binding contract as the offeror did not state that the only binding method of acceptance was the ones outlined in the offer. The rule can also be excluded by virtue of the circumstances of a particular case (Tallerman \& Co Pty Ltd v Nathan's Merchandise (Victoria) Pty Ltd, 1957).

The main disadvantage of the postal rule for acceptance is the period of uncertainty that it creates, as the parties have to wait in order to know whether a contract between them has been concluded or not, but also whether the revocation was effective or not (Gibson \& Fraser, 2005). It was decided relatively early on that during that period the risk is on the offeror who is obliged to keep the offer open (Adams $v$ Lindsell, 1818). The rationale behind this judgment is based on business efficiency, as otherwise, the offeror will have to acknowledge receipt of the acceptance. The offeree would then be obliged to acknowledge receipt of acceptance and so on and so forth. To break this ad infinitum spiral and avoid waste of time, the judge decided that the person having to bear the risk is the offeror, as he is the one proposing the good, unless there is a fault creating the 
delay or loss, then the risk will lie with the party at fault (Entores Ltd v Miles Far East Corporation, 1955; L J Korbetis v Transgrain Shipping BV, 2005). The offeror is also in control of the offer and could therefore take steps to diminish the potential risks (Evans \& Marshall, 1966). As Corbin and Perillo noted it "must be remembered that in the vast majority of cases the acceptance is neither lost nor delayed, and promptness of action is of importance in all of them" (Corbin \& Perillo, 1993). Consequently, the postal rule can be regarded as economically efficient as the performance of the contract can start as soon as possible, which outweighs the disadvantages caused by the allocation of the risks of loss or delay. ${ }^{3}$

To sum up, the three main consequences of the Adams v Lindsell case are; First, a posted acceptance prevails over a previously posted withdrawal of the offer which had not yet reached the offeree when the acceptance was posted. Second, acceptance takes effect on dispatch irrelevant whether it reaches the offeror or not or whether it arrives on time. Finally, the contract is made at the time of posting and therefore takes priority over another contract made after the original acceptance was posted.

\section{The Postal Rule: Revocation}

One of the areas in which the postal rule was put under pressure was whether the original offer was revocable and when the revocation come into effect? The time of revocation is important in relation to the commencement of an action required under a unilateral offer. Under the postal rule, the revocation of the offer is a complicated subject. Indeed, a dichotomy exists between the moment taken into consideration; letters of acceptance are relevant on posting and not when they arrived within the sphere of knowledge of the offeror. On the contrary, with regard to letters of revocation only come into effect when the letter revoking the offer is delivered (Jalil, 2011). The revocation letter must be received by the offeror to be an effective revocation (Hudson, 1966). Consequently, as much as the delay or non-delivery by the post is not important for the communication of the acceptance, as much as they play a role for the revocation. In order to fit the legal doctrine that an "irrevocable offer was a legal impossibility," the revocation must be possible at any time (Routledge $v$ Grant, 1828). The main problem is that this doctrine contradicts directly the postal rule as this doctrine requires that the offeree and the offeror to be bound simultaneously (Cooke v. Oxley, 1790). The concept is that any offer may be freely revoked up until the time that the full consideration requested is received (Nussbaum, 1936, pp. 922-923; McGovney, 1914).

\footnotetext{
${ }^{3}$ As Rawls said: "Businesses and individuals take informed risks based on uncertainties all the time; for example, the risk of relying on an as-yet uncertain communication may be willingly assumed so long as the expected benefit is positive relative to alternative courses of action" See: (Rawls, 2009, p. 215).
}

DEFOSSEZ, D. Acceptance sent through email; is the postal rule applicable? Law, State and Telecommunications Review, Brasilia, v. 11, no. 1, p. 23-46, May 2019. 
The landmark case is the ruling in Byrne $v$ Van Tienhoven. In this case, the judges were convinced that the plaintiff had accepted the original offer by posting a response before the letter of revocation was received. Denning LJ held in (Errington v Errington $v$ Woods, 1952, p. 295) that 'The father's promise ... could not be revoked by him once the couple entered on performance of the act, but it would cease to bind him if they left it incomplete and unperformed". It has been identified as an implied obligation in (Daulia v Four Millbank Nominees., $1978)^{4}$.

In Wald's Pollock on contract, it is stated that "on principle it is hard to see why the offeror may not revoke his offer. He cannot be said to have already contracted, because by the terms of his offer he was only to be bound if something was done, and it has not as yet been done, though it has been begun. Moreover, it may never be done, for the promisee has made no promise to complete the act and may cease performance at his pleasure. To deny the offeror the right to revoke is, therefore, in effect to hold the promise of one contracting party binding though the other party is neither bound to perform nor has actually performed the requested consideration. The practical hardship of allowing revocation under such circumstances is all that can make the decision of the question doubtful" (Pollock, 1906, p. 39). Already in 1906, there was some voices against the restriction of the freedom of the offeror to revoke his offer. The postal rule offers a protection which would otherwise leave the offeree in a less favourable position than the offeror (Macneil, 1964, p. 953).

Even after partial performance through the dispatch of the letter, an offeree is not bound to complete performance but may instead withdraw providing he does not injure any interest of the offeror in so doing (Pollock, 1906, p. 37; Anon., 1955).

\section{Justifications for the Postal Rule}

A number of justifications for the postal rule have been suggested in the past to demonstrate the utility of the rule and its rationale. Most of these

\footnotetext{
${ }^{4}$ However, implied obligations are a difficult subject. Lord Bridge noted in Scally $v$ Southern Health and Social Services Board "A clear distinction is drawn ... between the search for an implied term necessary to give business efficacy to a particular contract, and the search, based on wider considerations for a term which the law will imply as a necessary incident of a definable category of contractual relationship". In Crossley v Faithful \& Gould, Dyson LJ explained the process when a term is implied in law. He stated: "it seems to me that rather than focus on the narrow concept of necessity, it is better to recognise that to some extent at least, the existence and scope of standardised implied terms raise questions of reasonableness, fairness and the balancing of competing policy considerations". See: (Crossley v Faithful \& Gould, 2004).
} 
justifications have, however, long been dismissed on the ground that they are flawed.

The first justification is based on the traditional idea of the meeting of the minds or consensus ad idem. As explained earlier, this traditional idea stems from the case Adams $v$ Lindsell. In this perspective, the point when the meeting of the minds occurred and therefore an intention to be legally bound, is when the letter is dispatched, as otherwise the traditional rule would no more be valid (Evans \& Marshall, 1966). Indeed, if such was not the case and the dispatch rule was never introduced, then the acceptance of a contract send through the post would be based on a legal fiction since the point in time taken as the acceptance of the offer would be delayed in relation to the real point in time. Although one may argue that the knowledge of the offeror is as important as the intent of the offeree. Especially since the offeror might change his mind prior to receiving the letter and therefore, cannot be considered as having the consensus needed (Gardner, 1992, p. 171). All the benefits of the ruling in Adams disappear when the offeree withdraws or countermands his acceptance by a faster mean of communication, which reaches the offeror before the acceptance, as in the US case (Dick v. United States, 1949).

The court in Adams $v$ Lindsell was influenced by the consideration that if commerce were to be facilitated and business to prosper, then the offeree should be able to rely upon his acceptance as early as possible. This in turn would encourage him "to execute the contract secure in the knowledge that his expectations would not be defeated by a withdrawal of the offer" (Anon., 1955). Thesiger, L. J. argued in (Household Fire and Accident Insurance Co v Grant, 1874), for early protection of the offeree by stating that: "If the contract is not finally concluded, except in the event of the acceptance actually reaching the offeror (...) considerable delay in commercial transactions, in which dispatch is, as a rule, of the greatest consequence, would be occasioned". Mellish LJ pointed out in (Re Imperial Land Co of Marseilles (Harris' case), 1872) the mischievous consequences that would flow if the dispatch rule had not been adopted. He argued that "I have been forcibly struck with the extraordinary and very mischievous consequences which would follow if it were held that an offer might be revoked at any time until the letter accepting it had actually been received. (...) Every day, I presume, there must be a large number of mercantile letters received which require to be acted upon immediately (...) The merchant writes an answer accepting the offer and goes that instant into the market and purchases the goods in order to enable him to fulfill the contract (...) but (...) if the person who has sent the offer (...). may at any time, before he has received the answer, revoke his offer, the consequences might be very serious for the merchant".

The offeror is considered as having left the offer opened throughout the whole time that the offer takes to reach the offeree. Since the offer has the power 
to bind both parties, the acceptance of the offer is an exercise of that power. The offeror can be seen as having full power to determine the acts that constitute the acceptance. As soon as the offeror determine the acts, then the power is out of his reach as the offer has become effective (Payton, 2003, p. 185). This balance the power between the parties; the offeror has the power to determine the step to be taken for acceptance and the offeree has the power for the formation process. The offeror can, therefore, avoid the rule in Adams $v$ Lindsell by expressly stipulate that he is not to be bound until actual receipt of the acceptance, which is the next justification. Similarly, the offeror could have stated that the dispatch rule was not applicable. However, if the offeror indicates, either impliedly or expressly, that the rule applies then he should bear the risks and consequences link to the application of that rule.

Another type of legal fiction was used for the dispatch rule. In (Holwell securities Ltd $v$ Hughes, 1974), the post office was considered as the common agent of both parties which would hand over the acceptance to the offeror (Stimson, 1939, p. 781; Hodel, 1929, p. 275). This legal fiction of agency achieved a mechanical solution but is not adapted to commercial realities between distant parties. The reasoning of Thesiger LJ is the following: "how then are these elements of law to be harmonized in the case of contracts formed by correspondence through the post? I see no better mode than that of treating the post office as the agent of both parties". Unsurprisingly, such reasoning was soon rejected as unsatisfactory by Kay LJ in (Henthorn v Fraser, 1892). Indeed, the post office could not be treated as an agent as it did not deal with the content of the communication but instead it was just carrying the letter (Evans \& Marshall, 1966, p. 559; Samek, 1961, p. 39). This justification has long been discredited because the mere delivery of a letter does not complete the contract (Furmston \& Tolhurst, 2010, p. 4.102).

Another justification linked to the allocation of risks is that the rule is necessary to avoid endless chain of correspondence (Watnick, 2004). This justification was introduced in Adams $v$ Lindsell when Lord Ellenborough ruled that "no contract could ever be completed by the post. For if the defendants were not bound by their offer when accepted by the plaintiffs till the answer was received, then the plaintiffs ought not to be bound till after they had received the notification that the defendants had received their answer and assented to it. And so it might go on ad infinitum." Therefore, the court decided to draw the line as it is impossible that both parties are simultaneously aware of the communication due to the fact that post is "snail mail" subject to delay (Yamaguchi, 2004). The Adams case, adopted the rule to avoid "the extraordinary and mischievous" consequences which could follow if it were held that an offer might be revoked at

${ }^{5}$ At paragraph 683.

DEFOSSEZ, D. Acceptance sent through email; is the postal rule applicable? Law, State and Telecommunications Review, Brasilia, v. 11, no. 1, p. 23-46, May 2019. 
any time until the offeree was in the position of "accepting it had been actually received". (Household Fire and Accident Insurance Co v Grant, 1874; Re Imperial Land Co of Marseilles (Harris' case), 1872). It "would be perfectly possible to hold that the acceptance took effect when it came to the notice of the offeror, whether the offeree knew of this or not" (Peel, 2011, p. 2.031). It was believed that without the rule an offeree would not be able to know for certain whether he was legally bound by the contract or not. However, it is obvious that in any cases, one of the parties is going to suffer hardship, in this case the offeror instead of the offeree. This reasoning seems very modern, although decided nearly 200 years ago. Indeed, English law is known for its business-oriented approach, however, the outcome of this case is closer to modern law, which has seen the rise in the level of consumer protection, partially influenced by European law. The postal rule set the floor and background for modern consumer protection.

The dispatch rule is a somewhat compromise solution as highlighted by Nussbaum when he states that "However, the consideration doctrine stood in the way of holding irrevocable an offer made neither for value nor under seal (...). In this situation protection for the offeree could be attained only by the Adams $v$. Lindsell rule. This was the best solution that could be reconciled with the consideration doctrine" (Nussbaum, 1936, p. 925). The postal rule is often considered as the better evil (Macneil, 1964; Winfield, 1939).

\section{The exception to the postal rule: The Telex}

Through the decade, other forms of communication, much speedier, were invented. One of them was the telex. Unlike with telegram, with the introduction of the telex, the postal rule started to demonstrate its first flaws. The two classic cases in relation to whether the dispatch rule is applicable to modern form of communication. The test of instantaneousness was also stemming from the telex cases of Entores Ltd v Miles Far East Corpn (Fasciano, 1996).

In that case, it was held that a telex is a "virtually instantaneous" method of communication. As a result, when an acceptance is sent by telex "it is not until [the offeree's] message is received that the contract is complete". The court concluded that the contract was made when the acceptance was received by the plaintiffs because: “(...) so far as telex messages are concerned, though the dispatch and receipt of a message is not completely instantaneous, the parties are to all intents and purposes in each other's presence just as if they were in telephone communication, and I can see no reason for departing from the general rule that there is no binding contract until notice of the acceptance was received by the offeror". 
"The decisive factor which motivated Lord Denning's decision not to extend the application of the postal acceptance rule to telexes is the ability of the contracting parties to ascertain whether the acceptance has been received by the offeror" (O'Shea \& Skeahan, 1997). Indeed, with instantaneous means of communication, the parties will know if the acceptance has not been received. In (Brinkibon Ltd v Stahag Stahl und Stahlwarenhandelsgesellschaft $m b H, 1983$ ) Lord Wilberforce recognised the weakness of the rule on telex by referring to the considerable delay between the time when a message is sent by the offeree and the time that it comes to the attention of the offeror that may exist.

Lord Fraser noted, in not applying the postal rule to telex, that it was "convenient that the acceptor, being in the better position, should have the responsibility of ensuring that his message is received" (Brinkibon Ltd v Stahag Stahl und Stahlwarenhandelsgesellschaft $m b H, 1983)$. In this case the main question was whether the contract was concluded in the UK or in Austria, applying the acceptance rule, the court concluded that it was Austria (Poole, 2016, p. 50). It is the offeree who knows when the acceptance was dispatched, and he is best situated to check on its arrival. This is even more so as when the acceptance is sent through email, the offeree might request an automated notice of arrival or will get a delivery failure notice if there is a mistake in the address. Even if this receipt of notice cannot always be relied on, the offeree is, like with telex, in a better position than the offeror to ensure that the acceptance arrives (Mik, 2009, pp. 85-87).

\section{Internet contract: is the postal rule applicable to emails?}

We have seen the justifications advanced to keep the postal rule. Emphasis was put on the uncertainty concerning the moment of contract formation that the rule creates. This uncertainty does not exist in face-to-face communication or in distance contracting where an instantaneous method of communication is used. In both situations, all parties are aware of contract conclusion. On the contrary, in non-instantaneous communications, issues such as delay or failure of transmission are impossible to avoid. The example of the telex was brought in to show what is understood by instantaneous mean of communication. The lack of control over the letter was also highlighted.

E-mails are quite recent methods of contracting, however, they still pose problems. Indeed, is an email similar to contracting by post? If so then the postal rule should apply. Or is it rather closer to the telex?

Can Email Qualify as Instantaneous Means of Communication?

DEFOSSEZ, D. Acceptance sent through email; is the postal rule applicable? Law, State and Telecommunications Review, Brasilia, v. 11, no. 1, p. 23-46, May 2019. 
Several authors, including Hill, have expressed the view that email and other online contracting methods are instantaneous communications and, therefore, the general acceptance rule should apply (Hill, 2001). This reasoning might hold true in respect to website acceptances since there is no actual space in time between the sending and the acceptance of the offer, however in emails transmission, there is a gap in time similar to the one of contracting through the post. Indeed, there is a distinction to be made between the speed of the travel and the time between the dispatch and receipt (Coote, 1971).

The journey of an email is similar to the journey of a letter. First the sender must connect to his mailbox and draft a message, then the sender must press the button send when he is content of his message. The sending of the message is quick as long as the network is not too busy, and that the receiver's address was correctly entered. Once again, this looks like a familiar story; the correct entry of the address of the receiver. Similar to a letter, when the email enters the internet, it may be bounce from a one computer to many millions, before reaching the receiver mailbox (Christensen, 2001). At that point of time, the email is in the sphere of knowledge of the receiver who will need to open his mailbox in order to download the message (Al Ibrahim, et al., 2007, p. 49). As a result, an email's journey can take up to few minutes. This has nothing to do with the speed of the internet but depends entirely on the viability of the ISP and whether the service providers are busy or not (Fasciano, 1996; O'Shea \& Skeahan, 1997).

Delays are not unusual in email communication (Clark, 1997; Gardiner, 1994). Indeed, considerable delays may occur in email communication between when a message is sent and when it is received by the recipient, depending on the path over which the email is sent. For instance, an email sent from London to New York will start its journey from London internet service provider and then will go to another provider in the Atlantic before reaching the provider in New York. While an email between a person in France and Belgium will have a less long journey. Technically speaking emails cannot be regarded as instantaneous form of communication due to the gap in time between dispatch and receipt (Ho Park, s.d.). On the contrary, the telex is using a similar network as the telephone and which was therefore instantaneous.

In a Singaporean judgment, Rajah JC held that "(..) unlike a fax or a telephone call, it is not instantaneous. Emails are processed through servers, routers and internet service providers. Different protocols may result in messages arriving in an incomprehensible form. Arrival can also be immaterial unless a recipient accesses the email, but in this respect, email does not really differ from mail that has not been opened" (Chwee Kin Keong v Digilandmall.com Pte Ltd, 2005). According to this case, emails are non-instantaneous mean of communication. 
In Brinkibon, Lord Wilberforce acknowledged that a matter that might need to be looked at in the future is the arrival of an acceptance outside of office hours. ${ }^{6}$ The Scottish Law Commission recognised this problem in 2012 when stating that "in a context where the concept of office hours is relevant, a communication that reaches the addressee's system outside of those hours will become accessible for the purposes of the DCFR ... when the next period of business hours opens" (Scottish Law Commission, 2014, p. 2.17). Accessibility, therefore, seems to be the key to the receipt of electronic communication, as stipulated in Article 11 of the E-Commerce Directive and Article 10(2), UN Convention on the Use of Electronic Communications in International Contracts. Accessibility was also adopted in relation to the time of receipt of a message in Art I.-1:109 of the Draft Common Frame of Reference.

\section{Why Should We Apply the Postal Rule to Email Acceptance?}

The first and main reason for extending the postal rule to emails is that in the absence of any legislation which clearly and unequivocally establishes the moment when a contract is concluded through emails, the postal rule is bringing legal certainty. Although electronic commerce legislations have been enacted at both European and UK level, these legislations do not aim at substantially changing the rules on contract formation and do not provide any clarification with regard to acceptance sent through emails. For instance, Articles 9 to 11 of the Ecommerce Directive do not provide any framework instead they invite Member States to introduce legislation in case their national law does not recognise this type of transactions. ${ }^{7}$ The Regulations of Electronic Commerce 2002 do not have any provision indicating when a message is considered as having either been sent or received. The provisions of the Regulation are not applying to contracts concluded by email. Indeed, Section 11(2)(b) of the Regulation stipulated that "acknowledgment of receipt of the order (...) without undue delay and by electronic means", making it clear that it only addresses only orders where the email is not conveying acceptance but is only a proof of receipt of the order.

Indeed, unlike telex, emails are not instantaneous means of communication, there is a gap in time between the sending of the message by the offeree and the receipt by the offeror. Emails seems closer to letters than telex due to some technical features that were explained above. Therefore, using general

\footnotetext{
${ }^{6}$ At paragraph 42

${ }^{7}$ Article 9(1) "Member States shall ensure that their legal system allows contracts to be concluded by electronic means. Member States shall in particular ensure that the legal requirements to the contractual process neither create obstacles for the use of electronic contracts nor result in such contracts being deprived of legal effectiveness and validity on account of their as such as soon as it is received by the recipient. having been made by electronic means."
}

DEFOSSEZ, D. Acceptance sent through email; is the postal rule applicable? Law, State and Telecommunications Review, Brasilia, v. 11, no. 1, p. 23-46, May 2019. 
acceptance rule would bring business uncertainty regarding the conclusion or not of a contract. Indeed, unlike the post, email systems are equipped with failed delivery notice. On top of the failed delivery notice, if the email system is equipped with a notice of sending, the offeree might receive a message that his email was successfully sent. This makes the application of the postal rule easier than for the post. Indeed, the risk that a letter would not arrive because misaddressed is therefore lower with emails but still present.

Moreover, a problem is created with regard to the time of acceptance of a contract. Indeed, if the confirmation email is sent outside of office hours and the rule of formation of contract is based on the receipt of the acceptance, the next question is when is the receipt? Is it the time when the email arrives in the mailbox of the offeror or is it when the offeror takes knowledge of the email? For instance, a contract for the delivery of a piece of machinery that is to be delivery 3 days after the receipt of the acceptance. The offeree, after having received the approval of his boss, sent an email confirming the order, however such email is sent after business hours. Unfortunately, the offeror omitted to tell the offeree that he would be on holidays the whole week. Does that mean that the offeror is in breach of contract? Or is the contract starting the Monday morning after the holiday week of the offeror? Dickie argues that the email should be considered as received at the time it enters the offeror's ISP (Dickie, 1998; Reed, 1994; Reed, 1990). Applying the postal rule will avoid such uncertainty and create a definite time regarding to email contract conclusion.

Unlike telex, an email has more chances of not being delivered, due to failure of networks, hacking by third parties or incorrect email addresses and so on and so forth (Al Ibrahim, et al., 2007). At time, a computer can freeze upon sending a message and the offeree might need to resend the email as the message might not have been sent or might have been altered. Outlook regularly requests its user to sign in which stop any sending or receiving of email until the user signs in. Therefore, clarifying the rule applying to emails is of utmost importance in order to know when a contract is formed. Unlike, normal post, the time of sending is recorded by the ISP and therefore can be accessed later on, this in turn will ease the question of revocation which was, for normal mails, based on the good faith of the parties. Moreover, the risk of non-delivery, should like with post, lie with the offeror and not the offeree. Only with the postal rule can this risk be allocated on the offeror.

The message is considered to be out of the offeree's hands at the time the offeree sends the message. Similar to the situation with normal letter, in email communication, it can be said that the offeror keeps the offer throughout the whole time that the offer is dispatched. Here again, as soon as the offeror determine the acts, then the power is out of his reach as the offer has become effective. Using a 
similar approach than the one of the postal rule, Article 15 of the UNCITRAL Model Law on Electronic Commerce states that: "Unless otherwise agreed between the originator and the addressee, the dispatch of a data message occurs when it enters an information system outside the control of the originator or of the person who sent the data message on behalf of the originator." Consequently, the idea that when the dispatch of the message is when the message is out of the reach of the originator is similar to the one that the letter is dispatched when it is put in a mailbox (Al Farhan, 2002).

In the US, the legislation regarding this topic rejects the application of the postal rule for email transactions and adopt the general receipt rule, for the acceptance to be considered as effective. Paragraph 64 of the Restatement (Second) of Contracts dealing with an acceptance by telephone or teletype states that "acceptance given by telephone or other medium of substantially instantaneous two-way communication is governed by the principles applicable to acceptances where the parties are in the presence of each other". The rationale is that when the parties are in each other's presence, the offeree can accept without fearing that the offeror might attempt to revoke his offer or whether he will not receive the acceptance. The question of revocability is therefore not an issue. Where the parties are not in each other's presence but are able to communicate with each other without any substantial lapse of time, the situation is similar and the governing principles are the same. The acceptance sent by mail is dealt with in paragraph 66 of the Restatement (Second) of Contracts which states that "An acceptance sent by mail or otherwise from a distance is not operative when dispatched, unless it is properly addressed and such other precautions taken as are ordinarily observed to insure safe transmission of similar messages". The main difference between US legislation and the UK is that the Uniform Electronic Transaction Act 1999 (UETA 1999) refers to both instantaneous and substantially instantaneous means of communication, as can be concluded from the reading of Section 15. Emails can be regarded as substantially instantaneous means of communication. The UETA 1999 clarifies the moment when an electronic message should be considered as having been received by the recipient. According to Section 15, an electronic record is deemed to be sent when it is properly addressed or directed to another recipient, in a form capable of being read by the other parties' system and when it is out of the control of the sender. However, Section 15 does not establish when the acceptance becomes effective and the contract is formed. The only clarification is in Section 15(b) which stipulates that "an electronic record is deemed received when it enters an information processing system designated by the recipient for receiving such messages (e.g., home office), and "it is in a form capable of being processed by 
that system." Section 15 of the UETA 1999 closely follows Article 15 of the UNCITRAL Model Law however adding a bit more clarity (Poggi, 2000).

The Uniform Computer Information Transactions Act (UCITA) 1999 indicates explicitly the the applicable rule is the general rule on contract. Article 215 provides that electronic acceptance takes effect only at the time of receipt, regardless of whether the person is aware of that receipt. ${ }^{8}$ Article 203 (4) states that "if an offer in an electronic message evokes an electronic message accepting the offer, a contract is formed ... when an electronic acceptance is received". This approach creates a great problem with acceptance sent after working hours, meaning that a contract is formed, but revoked few hours later. For instance, an offer is sent through email and the offeree sent his acceptance at 18h01, just after the office closed on a Friday afternoon. On the Saturday, the offeree changed his mind and is under the belief that the person would not check his emails until Monday morning. The revocation arrived after the acceptance; however the revocation will come to the knowledge of the offeror before the acceptance as the email containing the revocation will be higher in list of emails than the acceptance. However, if the postal rule is applied, then the offeree will know that he will be bound at the moment that he clicks on the bottom 'send.' Furthermore, such a rule could not be applied in the UK as the Regulation focuses on the accessibility, rather than relying on the concept of being able to access (Ramberg, 2001). Indeed, the main aim of the Regulation is to provide transparency and enumerate the information that should be provided (Murray, 2005). The main idea is consumer protection. As was explained higher, the author sees the postal rule as a premise of consumer protection, by allocating the risk on the offeror.

\section{Conclusion}

Since 1818 and the Adams $v$ Lindsell case, the postal rule has greatly changed and developed in order to fit the formation of modern communications. The postal rule is one of the controversial parts of the law of contract. The longdistance communication raises some questions regarding to the time and type of contract formation. In today's modern society, debates emerged as to whether the postal rules could apply to contract through emails. Contracting by email is the digital equivalent of the postal system.

${ }^{8}$ Article 102 (A) defines receipt as "“'In the case of an electronic notice[...] coming into existence in an information processing system or at an address in that system in a form capable of being processed by or perceived from a system of that type by a recipient, if the recipient uses, or otherwise has designated or holds out, that place or system for receipt of notices of the kind to be given and the sender does not know that the notice cannot be accessed from that place."

DEFOSSEZ, D. Acceptance sent through email; is the postal rule applicable? Law, State and Telecommunications Review, Brasilia, v. 11, no. 1, p. 23-46, May 2019. 
This paper analysed the rationale behind the rule and demonstrated its continuing existence in modern society. The postal rule was introduced to create a fair result in particular situations of acceptance sent through the post. Finding the acceptance effective on dispatch protected to offeree as the offeror could never deny the existence of a contract on basis of delay in arrival or non-arrival. However, soon after its introduction, the rule was already criticised due to its problematic allocation of risk of loss. The non-fault-based risk of loss led to attempt of dismissing the rule, but the partisans of the rule demonstrated once again that the rule achieved a fair result in particular cases. The primary function of the postal rule was not to allocate the risk of loss or delay. Rather such allocation of risk is an undesirable side effect which could be changed if the postal rule was extended to email communication.

The postal rule was created as an exception to the general offer and acceptance rules. Under the general rule of offer and acceptance, an offer could be withdrawn or revoked any time before its acceptance. The precise moment when the offer was accepted or revoked is often creating conflicts. The postal rule was developed to solve the problematic issues between offeror and offeree. Especially, because the feature of distant communication raised some particular issues. Post is often referred as "snail mail" because it could take a long period of time to get to the recipient. The gap in time that exists between the dispatch of the acceptance and its receipt by the offeror, is also present in email's communication. As Treitel concluded; "courts in applying the postal rule aim to bring a rationale of necessity and predict that if the contract were to come into force it can best be achieved on sending the acceptance" (Treitel, 1991, p. 24). Such certainty is necessary for e-mail acceptance, although the risk of delay or loss is reduced with emails.

The gap between the dispatch and the receipt, which potentially can create revocation issue, is well resolved by the postal rule. Indeed, as Lord Wilberforce held in Brinkibon Ltd $v$ Stahag Stahl und StahlwarenhandelsGesellscaft $\mathrm{mbH}$, "the senders and recipients may not be the principals to the contemplated contract. They may be servants or agents with limited authority. The message may not reach, or be intended to reach, the designated recipient immediately: messages may be sent out of office hours, or at night, with the intention, or upon the assumption, that they will be read at a later time. There may be some error or default at the recipient's end which prevents receipt at the time contemplated and believed in by the sender. The message may have been sent and/or received through machines operated by third persons. And many other variations may occur. No universal rule can cover all such cases ..."9. Lord Wilberforce with this sentence expressed the need of a new rule which could be inspired by the postal rule. That new rule could keep the advantage of lifting the

${ }^{9}$ At paragraph 42

DEFOSSEZ, D. Acceptance sent through email; is the postal rule applicable? Law, State and Telecommunications Review, Brasilia, v. 11, no. 1, p. 23-46, May 2019. 
uncertainty created by the gap between the dispatch and the receipt, while recognising that the risk should be on the offeree since, with the new mean of communication, he is the party more in control of the situation. The revocation issue could be specifically addressed.

Posner rightly pointed out that the postal rule is economically efficient as it "enables the offeree to begin performance (or preparatory measures) but does not delay the offeror's performance, which in any event cannot begin until the offeror received the acceptance, for until then he wouldn't know whether there was a contract" (Posner, 2007, p. 103). However, it can be argued that the efficiency depends upon the individual transaction. In general, the argument makes sense; the economic efficiency of the postal rule lies in the fact that it allows performance to commence as soon as possible. At the same time, this efficiency must be balanced with the risks of loss or delay putting the risk on the party that is less able to minimise the risks. As Gardner noted: "If anything, one would have thought it was more efficient to make each type of letter effective only on delivery. After all, it is the sender, rather than the addressee, who is in control of a letter's transmission. This would mean reversing the rule regarding acceptances. If the rule were against the offeree (that is, required delivery to the offeror), he could respond by using the recorded delivery service, sending multiple communications, etc. As things stand however it is the offeror the law encourages to guard against accidents in the post, yet ... he is much less well placed to do so" (Gardner, 1992, p. 177). The assumption that the postal rule is economically efficient can be questioned, especially in relation to modern and much faster means of communication. Such method reduces the potential of revocation at the same time as reducing the time before performance could start. But the postal rule was also introduced to allow a faster performance. The postal rule "has the merit of closing the deal more quickly and enabling performance more promptly" (Corbin \& Perillo, 1993, p. 3.24).

With the elapse of time, the rule was subject to more and more pressure with some author arguing that the rule existed because there was a need for a rule, leaving aside the fact that the rule solved real problems. With the fast means of communication, the benefits of the postal rule seem to be outweighed by its disadvantages. Even though its drawbacks seem numerous, the positive impact the rule created should not be lost. Indeed, the postal rule is based on the principle of pre-contractual good faith, a principle with which English Contract law has a love-hate relationship.

\section{References}

ADAMS v LINDSELL (1818) 1 B \& Ald 681.

DEFOSSEZ, D. Acceptance sent through email; is the postal rule applicable? Law, State and Telecommunications Review, Brasilia, v. 11, no. 1, p. 23-46, May 2019. 
AL FARHAN, F. The Impact of the UNCITRAL Model Law on international legal systems Saudi Arabia information technology development from a legal perspective. 2002. Retrieved from: https://pdfs.semanticscholar.org/0c48/9cd7e6778cefc04feece56e2b7eca3 0b9d97.pdf

AL IBRAHIM, M. Ala'eldin, A. \& Tahat, H., The Postal Acceptance Rule in the Digital Age. in Journal of International Commercial Law and Technology, Vol. 2, Issue 1, 2007 p. 47.

ANON. Acceptance By Mail: Adams v. Lindsell. in Indiana Law Journal, Vol. 25, Issue 2, 1995, p. 202.

ANON. Contract Law. 5th ed ed. s.1.:Psychology Press, 2006.

ARANHA, M. I. Direito das Telecomunicações: histórico normativo e conceitos fundamentais. Coleford, UK: Laccademia Publishing, 2014.

BALDWIN, R., Cave, M. \& Lodge, M. eds., The Oxford Handbook of Regulation. Oxford: Oxford University Press, 2010.

BÖCKENFÖRDE, E.-W. Escritos sobre derechos fundamentales. BadenBaden: Nomos, 1993.

BRESSAN v SQUIRES (1974) 2 NSWLR 460.

$\begin{array}{llllll}B R I N K I B O N & \text { Ltd } & v & \text { STAHAG } & \text { STAHL } & \text { UND }\end{array}$

STAHLWARENHANDELSGESELLSCHAFT mbH (1983) 2 AC 34, at 41.

BYRNE \& Co v LEON VAN TIEN HOVEN \& Co (1880) 5 CPD 344.

CARLSSON, U. The Rise and Fall of NWICO: From a Vision of International Regulation to a Reality of Multilevel Governance. in Nordicom Review, Volume 2, 2003, pp. 31-68.

CHRISTENSEN, S. Formation of Contracts by Email - Is it Just the Same as the Post? in Queensland University Technology Law \& Justice Journal, Vol. 1, Issue 1, 2001, p. 2.

CHWEE KIN KEONG and Others v DIGILANDMALL.COM Pte Ltd (2004) 2 SLR 594.

CHWEE KIN KEONG v DIGILANDMALL.COM Pte Ltd (2005) SGCA 2.

CLARK, B. The E-Mail Acceptance Rule. June Proctor, 1997, p. 13.

COOKE $v$ OXLEY (1790) 3 T. R. 653.

DEFOSSEZ, D. Acceptance sent through email; is the postal rule applicable? Law, State and Telecommunications Review, Brasilia, v. 11, no. 1, p. 23-46, May 2019. 
COOTE, B. The Instantaneous Transmission of Acceptances. NZULR, vol. 4, 1971, p. 331.

CORBIN, A. \& PERILlO, J. Corbin on Contracts. s.l.:rev. ed, 1993.

CROSSLEY $v$ FAITHFUL \& GOULD (2004) EWCA Civ 293.

DAULIA v FOUR MILLBANK NOMINEES. (1978) 2 All ER 557.

DICK $v$ UNITED STATES (1949) 82 F. Supp. 326.

DICKIE. When and Where are Electronic Contracts Concluded? Northern Ireland Legal Quarterly, 1998.

ENTORES Ltd $v$ MILES FAR EAST CORPORATION (1955) 2 QB 327.

ERK, J. Austria: A Federation without Federalism. Publius, Winter, 34(1), 2004, p. 1-20.

ERRINGTON $v$ WOODS (1952) 1 KB 290.

EVANS, D. \& MARSHALL, D. The Anglo-American Mailing Rule: Some problems of offers and acceptance in contracts by correspondence. International and Comparative Law Quarterly, vol. 15, 1996, p. 553.

FASCIANO, P. Internet Electronic Mail: A Last Bastion for the Mailbox Rule. Hofstra Law Review, vol. 25, 1996, p. 1542.

FURMSTON, M. \& TOLHURST, G. Contract Formation - Law and Practice. s.1.:OUP, 2010.

GARDINER, J. The postal rule in contract law and the electronic marvels. Current Commercial Law, vol. 2, 1994.

GARDNER, S. Trashing with Trollope: A Deconstruction of the Postal Rules in Contract. Ox Jo LS, vol. 12, 1992, p. 170.

GIBSON, A. \& FRASER, D. Business Law. 2nd ed s.1.: Pearson Education, 2005.

HÄBERLE, P. Die Wesensgehaltgarantie des Art. 19 Abs. 2 Grundgesetz. Karlsruhe: C.F.Müller, 1962.

HARE $v$ NICHOLL (1966) 2 QB 130.

HENTHORN $v$ FRASER (1892) 2 Ch 27.

HILL, S. Flogging a Dead Horse - The postal acceptance rule and e-mail. Journal of Contract Law, Vol. 17, Issue 2, 2001, p. 151.

HO PARK, S. A Comparative Legal Research on Contract Formation via Electronic Means: Time Lag of Contract Creation in the International

DEFOSSEZ, D. Acceptance sent through email; is the postal rule applicable? Law, State and Telecommunications Review, Brasilia, v. 11, no. 1, p. 23-46, May 2019. 
Sales Transaction. n.d. Retrieved from:

https://www.google.com.br/url?sa=t\&rct=j\&q=\&esrc=s\&source=web\&c $\mathrm{d}=3 \& \mathrm{cad}=\mathrm{rja} \&$ uact $=8 \& \mathrm{ved}=0$ ahUKEwi70on5iszSAhVFQZAKHRHEA

NMQFgguMAI\&url=http $\% 3 \mathrm{~A} \% 2 \mathrm{~F} \% 2 \mathrm{Fktra} . c \mathrm{cpshost} . \mathrm{com} \% 2 \mathrm{Fh}$ board $\%$ 2Fdownload.php\%3F\%26bbs id\%3De12\%26page\%3D\%26type\%3D1\% 26doc num $\% 3 \mathrm{D} 40 \% 26 \mathrm{PHPSESSID} \% 3$

HODEL. Communication of Acceptance Between Parties at a Distance. CORN. L. Q., vol. 15, 1929 p. 273.

HOLWELL SECURITIES Ltd $v$ HUGHES (1974) 1 WRL 155.

HOUSEHOLD FIRE AND ACCIDENT INSURANCE Co v GRANT (1874) All ER Rep 919.

HOUSEHOLD FIRE AND ACCIDENT INSURANCE Co $v$ GRANT (1874) 2 NSWLR 460.

HUDSON. Revocation of postal Acceptance. LQR, vol. 82, 1966, p. 169.

HUMBOLDT, W. On Language: On the Diversity of Human Language Construction and its Influence on the Mental Development of the Human Species. Cambridge: Cambridge University Press, 1999.

IGNATIUS $v$ BELL (1913) 2 F MSLR 115.

IMPERIAL LAND Co of MARSEILLES (Harris' case) (1872) LR 7 Ch 587.

JALIL, A. Clarification of Rules of Acceptance in Making Business Contracts. Journal of Politics and Law, vol. 4, 2011, p. 109.

L J KORBETIS $v$ TRANSGRAIN SHIPPING BV (2005) EWHC (QB) 1345.

LEVY, B. \& SPILLER, P. Regulations, Institutions and Commitment. Cambridge: Cambridge University Press, 1996.

LUHMANN, N. Law as a Social System. Oxford: Oxford University Press, 2004.

MACNEIL, I. Time of acceptance: too many problems for a single rule. Pa $\mathbf{L R}$, vol. 112, 1964, p. 947-979.

McGOVNEY. Irrevocable Offers. HARv. L. REv., vol. 27, 1914, p. 644.

MIK, E. The Effectiveness of Acceptances Communicated by Electronic Means, or-Does the Postal Rule Apply to E-mail? JCL, vol. 26, Issue 1, 2009, p. $68-96$. 
MURRAY, A. Contracting electronically in the shadow of the e-commerce directive. In: The New Legal Framework for E-Commerce in Europe. s.1.: Hart Publishing, 2005, p. 67-92.

NUSSBAUM. Comparative Aspects of Anglo-American Offer-and-Acceptance Doctrine. COL. L. REv., Vol. 36, Issue 6, 1936, p. 920-929.

O'Sullivan, J. \& Hilliard, J. The Law of Contract. Oxford: Oxford University Press, 2006.

O'SHEA, K. \& SKEAHAN, K. Acceptance of Offers by E-Mail How Far Should the Postal Acceptance Rule Extend? Queensland U. Tech. L.J., vol. 13, 1997, p. 247-262.

PAYTON, D. Electronic Contracts. Penglais: DPhil Thesis Aberystwyth University, 2003.

PEEL, E. Treitel The Law of Contract. 13 ${ }^{\text {th }}$ ed. s.1.: Sweet \& Maxwell, 2011.

POGGI, C. Electronic Commerce Legislation: An analysis of European and American Approaches to Contract Formation. Va. Journal of International Law, vol. 41, 2000, p. 224.

POLLOCK, F. Principles of Contracts. $3^{\text {rd }}$ ed. s.1.: Williston, 1906.

POOLE, J. Casebook on Contract Law. Oxford: Oxford University Press, 2016.

POSNER, R. Economic Analysis of Law. $7^{\text {th }}$ ed. New York: Aspen Publishers, 2007.

PRICE, M. E. \& NOLL, R. G. A Communications Cornucopia: Markle Foundation Essays on Information Policy. Washington, DC: Brookings Institution Press, 1998.

RAMBERG, C. The ECommerce Directive and Contract Formation in a Comparative Perspective. European Law Review, vol. 26, 2001, p. 429.

RAWLS, A. Contract formation in an Internet Age. Columbia Science and Technology LR, vol. 10, 2009, p. 200.

RE IMPERIAL LAND Co of MARSEILLES (Harris' case) (1872) LR 7 Ch 587.

REED, C. EDI - Contractual and Liability Issues. Computer Law \& Practice, vol. 6,1990 , p. 36.

REED, C. Advising Clients on EDI Contracts. Computer Law \& Practice, vol. 10, 1994, p. 90. 
ROSE-ACKERMAN, S. \& LINDSETH, P. L. (eds.) Comparative Administrative Law. Cheltenham, UK: Edward Elgar, 2010.

ROUTLEDGE $v$ GRANT (1828) 130 ER 920.

SAMEK, R. A Reassessment of the Present Rule Relating to Postal Acceptance. ALJ, vol. 35, 1961, p. 38.

SCOTTISH LAW COMMISSION. Discussion Paper on Formation of Contract, s.1.: Discussion Paper No 154, 2014.

SIMPSON, A. W. B. A History of the Common Law of Contract: The Rise of the Action of Assumpsit. Oxford: Clarendon Press, 1987.

STIMSON. Effective Time of an Acceptance. MINN. L. REv., vol. 23, 1939, p. 776.

STORER $v$ MANCHESTER CITY COUNCIL (1974) 3 All ER 824.

TALLERMAN \& Co Pty Ltd $v$ NATHAN'S MERCHANDISE (Victoria) Pty Ltd (1957) 98 CLR 93.

TAYLOR $v$ LAIRD (1856) 1 H \&amp N 266.

TREITEL, G. The Law of Contract. $8^{\text {th }}$ ed. London: Sweet and Maxwell, 1991.

WATNICK, V. The Electronic Formation of Contracts and the Common Law "Mailbox Rule". Baylor Law Review, vol. 56, 2004, p. 175.

WINFIELD, P. Some Aspects of Offer and Acceptance. LQR, Vol. 120, 1939, p. 499.

YAMAGUCHI, M. The Problem of Delay in the Contract Formation Process: A Comparative Study of Contract Law. Cornel International Law Journal, vol. 37, Issue 2, 2004, p. 357-388.

YATES BUILDING Co. Ltd $v$ RJ PULLEYN \& SON (York) Ltd (1975) 237 EG 183. 